\title{
ЕКСПОРТ ЗЕРНА: СТАН, ПРОБЛЕМИ ТА ПЕРСПЕКТИВИ
}

\author{
Соловей Марина Сергіївна \\ аспірант \\ Сумський національний аграрний університет (м.Суми, Україна) \\ ORCID: 0000-0003-4206-7433 \\ marusja.sol@gmail.com
}

В даний час Україна є одним із світових лідерів з експорту сільськогосподарської продукиії. Метою написання статті є аналіз ситуації на ринку зерна, визначення тенденцій, ємності ринку зерна та експортного потенціалу України.

В статті зроблено огляд експортного потенціалу ринку зурна в Україні та світі. Аналізуючи данні ми дійшли наступних висновків. Україна займає 7,5 відсотків загального світового експорту пшениці, що ставить ії на шосте місце в світі. Позитивні тенденції щодо зростання відсотку експорту в порівнянні з 2018 роком на 15,5 відсотків, що свідчить про поступовий вихід України в першу трійку експортерів зерна.

В статті зроблено висновок, що зберігаючи високі темпи нарощування обсягів виробниитва сільськогосподарської продукції, агропромисловий сектор має значний додатковий нереалізований потенціал щодо нарощування експорту продукції з доданою вартістю. Подальший його розвиток (за умови стійкого забезпечення продовольчої безпеки держави) здатен не лише закріпити за Україною статус надійного постачальника якісного доступного продовольства на світовий ринок, але і стати потужним рушієм розвитку економіки та зростання добробуту населення, сприяти сталому розвитку сільського господарства, реалізовуючи при цьому потужний виробничий та експортний потенціал.

Ключові слова: ринок зерна, експортний потенціал, зовнішня торгівля, європейська інтеграція

DOI: https://doi.org/10.32845/bsnau.2019.2.8

Постановка проблеми у загальному вигляді. Україна в даний час $є$ одним із світових лідерів з експорту сільськогосподарської продукції, а сільськогосподарська галузь це одна з провідних галузей економіки України, яка є найпривабливішою для інвестицій. Завдяки сприятливому клімату та географічному положенню, унікальним природним ресурсам, великим площам родючої ріллі та високому бонітету грунтів Україна має гарні позиції для отримання статусу світового лідера сільськогосподарського виробництва.

В процесі розвитку державності динаміка виробництва сільськогосподарської продукції постійно збільшувалася, на сьогодні на нього припадає $12 \%$ ВВП та $17 \%$ зайнятих 78,9\% сільськогосподарських угідь в Україні $є$ орні землі (рілля), а виробництво сільськогосподарських культур становить приблизно три чверті сільськогосподарського виробництва, порівняно з двома третинами в середині 1990-х. На сьогодні АПК посів місце провідної галузі (донора) національної економіки, фактично формуючи економічний профіль країни.

Сприяння підвищенню ефективності експортного потенціалу АПК забезпечує зростання іноземних валютних надходжень, що має вагоме значення для економічної безпеки країни. Тому розвиток експортоорієнтованих вітчизняних аграрних підприємств в умовах євроінтеграції є одним з пріоритетних завдань державної політики, що зумовлює актуальність дослідження даної проблематики.

Питання експорту зерна Україною постійно знаходиться в полі зору багатьох вітчизняних науковців і на сьогодні представлено широким спектром наукових досліджень. Серед основних можна виділити таких як: В.Г. Андрійчука (Андрійчук В.Г., 2015), В.І. Бойка (Бойко В.І., 2004), Боднар О. В. (Боднар О. В., 2010), С.В. Дельз (Дельз С.В., 2016), Ю.Є. Кирилова (Кирилов Ю.Е., 2005), О.Є. Куценко І.В. (Куценко І.В., 2016), Т. М. Мельник (Мельник Т.М., 2010), М.Р. Родіонова (Родіонова М.Р., 2014), Р.П. Саблука (Саблук Р.П., 2009) та інших.

Формування цілей статті. Метою даного дослі-

дження є аналіз ситуації на ринку зерна, визначення тенденцій та ємності ринку і оцінка експортного потенціалу України.

Методи дослідження. У дослідженні були використані такі методи, як метод аналізу при оцінці ринку зерна, метод порівняння при аналізі експортного потенціалу ринку зерна країн світу, метод логічного узагальнення при підведенні підсумків проведеного дослідження

Результати дослідження. В умовах інтеграції України до світової економіки розвиток вітчизняного експортного потенціалу має стати прискорювачем економічного зростання, стабілізаційним фактором та головним джерелом накопичення валютних резервів. Після економічної кризи в Україні 2013- 2015 років на фоні втрати частини територій Донецької та Луганської областей, анексії Криму та проведення АТО на сході держави, коли реальний ВВП країни знизився на $16 \%$, а темпи інфляції зросли майже до 50\%, економіка постійно зростає на рівні 2,5\% та 3,3\% на рік, тоді як темпи інфляції знижуються. За підсумками 2018 року рівень інфляції склав 9,8\%, а реальний ВВП України демонструє стабільну динаміку зростання показників на 3,3\%. Основними галузями, які формують ВВП, залишаються промисловість, сільське господарство та торгівля. Крім того, за останні роки спостерігається помітне нарощення питомої ваги в структурі ВВП сільського господарства - 3 8,4 \% у 2010 до 11,9 \% у 2018 році (зростання АПК 1,2 млрд. доларів США). 3 точки зору отримуваних доходів (що впливає на формування ВВП) Україна належить до експортоорієнтованих держав - в 2018 році саме експорт української сільськогосподарської продукції забезпечив 42,5 \% валютних надходжень у загальній структурі експорту (Україна в 2018 році встановила рекорд з експорту сільгосппродукції, 2018).

Сьогодні Україна залишається одним з провідних світових експортерів зерна та рослинних олій, експорт яких почав швидко зростати у період з кінця 1990-х років, а в 2018 році експорт продукції АПК з України збільшився на 5\% порівняно з 2017 роком і склав рекордні 18,8 мільярдів доларів. Більша частина експорту продовольчої продукції з України є

Вісник Сумського національного аграрного університету

Серія «Економіка і менеджмент», випуск 2 (80), 2019 
первинною продукцією для подальшої переробки, а імпорт, у свою чергу, більше змішаний, при цьому первинна та перероблена продукція для кінцевого споживання становить майже $60 \%$ імпорту агропродовольчих товарів. У період з 2005 по 2018 роки як обсяг сільськогосподарського виробництва, так і загальна факторна продуктивність в Україні зростали зі швидкістю, що значно перевищує середні показники в світі, а саме понад 4\% та 3,1\% на рік відповідно. При темпах росту обсягів торгівлі, що вимірюється двозначними цифрами, та інвестиціях, що надходять в український сектор агробізнесу, Україна відіграє все більшу роль у глобальній продовольчій безпеці.

За останнє десятиліття експорт зерна з України збільшився на 77\%. За січень-вересень 2019 року, частка експорту продукції АПК зросла в загальній структурі експорту до 42,1\% у порівнянні з 37,1\% у 2018 році. Частка імпорту агропродовольчої продукції в загальній структурі імпорту України залишилася на тому ж рівні.

За дев'ять місяців 2019 року загальний обсяг експорту всіх товарів з України склав 37,1 млрд. дол. США, при цьому експорт агропродовольчої продукції - 15,6 млрд. дол. США, а експорт продукції рослинництва - 9 млрд. дол. США (58\%). В товарній структурі експорту за дев'ять місяців 2019 року порівняно 3 аналогічним періодом 2018 року найбільше зросли поставки з України продукції рослинництва - на $36 \%$ або на 2,4 млрд. дол. США. Основні позиції торгівлі України агропродовольчою продукцією - це експорт кукурудзи - 24\%, соняшникової олії - 19\% та пшениці-16\%. Нарощення поставок продукції рослинництва відбулося в основному за рахунок збільшення експорту кукурудзи - на 1,4 млрд. дол. США або на 61\%. Також на $12 \%$ або на 241 млн. дол. США зріс експорт готових харчових продуктів (Україна нарощує експорт агропродовольчої продукції, 2019).

Досліджуючи експорт зерна з України, на нашу думку доцільним є розглянути місце України на світовому ринку. Починаючи з 2000 року, США, Європейський Союз, Канада, Австралія, Аргентина, Україна та інші країни Причорноморського регіону складали в середньому близько 90 відсотків світового експорту пшениці. Країни Східної Європи, Україна, Росія, Казахстан разом складають $51 \%$ прогнозованого збільшення експорту зернових до 2022 року. Світове виробництво пшениці у 2019/20 роках посідає друге місце за обсягами виробництва (768 млн. т) після кукурудзи (понад 1,09 мільярда тонн). (Таблиця 1)

Таблиця 1

Виробництво та експорт пшениці (вибрані країни)

\begin{tabular}{|l|r|r|r|r|r|}
\hline \multicolumn{1}{|c|}{ Регіон } & $\begin{array}{c}\text { Виробництво (тис. т.) } \\
\text { середне за 2016-2018 pp. }\end{array}$ & $\begin{array}{c}\text { 3ростання \% } \\
2009-2018 \text { pp. }\end{array}$ & $\begin{array}{c}\text { Вартість експорту пшениці } \\
\text { (млрд. дол. США) 2018 p. }\end{array}$ & $\begin{array}{c}\text { У \% від загального світового } \\
\text { експорту пшениці }\end{array}$ & $\begin{array}{c}\text { 3ростання експорту \% } \\
2009-2018 \text { рр. }\end{array}$ \\
\hline ЄС & 130950 & 0,97 & 22,6 & 22,1 & 2,5 \\
\hline РФ & 76437 & 5,74 & 8,4 & 20,5 & 13,8 \\
\hline США & 53824 & $-1,64$ & 5,7 & 13,2 & $-1,5$ \\
\hline Канада & 31298 & 2,61 & 5,5 & 7,5 & 3,1 \\
\hline Австралія & 23339 & $-2,33$ & 3,1 & 7,3 & -4.1 \\
\hline Україна & 25603 & 4,31 & 2,4 & 5,9 & 15,5 \\
\hline Аргентина & 18794 & 6,53 & & 11,6 \\
\hline
\end{tabular}

Джерело: Розраховано за даними (Leading corn-exporting countries worldwide 2018/19, 2019)

Аналізуючи дані таблиці, можна зазначити, що Україна відвантажила 7,3\% від загального світового експорту пшениці у 2018 році, що ставить її на 6 місце в світі за цим показником. Позитивні тенденції щодо зростання відсотку експорту з України у 2018 році порівняно з 2009 роком на 15,5\% свідчить про поступовий вихід України в першу трійку експортерів зерна.

За прогнозами, США залишаться домінуючим експортером пшениці та грубого зерна. Україна з 2014 року була одним з найбільш швидко зростаючих експортерів пшениці: Аргентина (на 31,7\%), Україна (на 31,1\%) та Болгарія (на 22,9\%). Україна поступово переходить від чистого імпортера сільськогосподарських товарів до чистого експортера, частково через зменшення росту населення та рівне споживання на душу населення, що обмежує внутрішній попит. Зростання виробництва також сприяло покращенню показників експорту, давши Україні змогу увійти до вісімки основних світових країнекспортерів, серед яких Європейський Союз, США, Канада, Аргентина та Австралія. Це відбулося завдяки значному покращенню продуктивності, ціновій конкурентоспроможності, географічній близькості України до Європейського Союзу (ЄС) та ринків ключових імпортерів і сприятливим торговельним відносинам з Китаєм. Зростання імпорту зернових в Північну Африку та Близький Схід також стимулює зростання експорту зернових з України.

Якщо брати до уваги експорт кукурудзи, його світовий обсяг в 2018 році склав 33,9 млрд. дол. США, що на 11,9\% більше порівняно з 2017 роком. 32014 року вартість експортованої кукурудзи зросла в середньому на 2,3\% для всіх країн-експортерів, коли поставки кукурудзи оцінили в 33,2 млрд. дол. США. Країни Північної Америки протягом 2018 року отримали найвищу вартість у доларах від експорту кукурудзи, ці поставки були оцінені в 13,6 мільярдів доларів, або 40,1\% від загальної кількості у світі. На другому місці опинилася Європа з 29,6\%, країни Латинської Америки відвантажили 25,6\% світової вартості експорту кукурудзи (Таблиця 2).

Аналізуючи дані таблиці 2, можна сказати, що за обсягами виробництва кукурудзи (28,5 млн. т) Україна поступається лише Сполученим Штатам (62,0 млн. т), а серед провідних країн-експортерів кукурудзи Україна займає четверте місце після таких країн, як США, Аргентина та Бразилія, та її доля ринку складає 10,3 відсотки від загального світового експорту.

Країни, які продемонстрували найбільший позитивний чистий експорт кукурудзи протягом 2018 року: Сполучені Штати 12,9 млрд. дол. США (чистий надлишок експорту збільшився на 19,4\% з 2014 року), Аргентина 4,2 млрд. дол. США (збільшення на 19,6\%), Бразилія 4,1 млрд. дол. США (на $3,8 \%$ та Україна 3,5 млрд. дол. США (на 10,7\% більше). Україна протягом кількох років переросла в конкурентоспроможного експортера кукурудзи (28,5 млн. т. у 2018 р.), поступаючись лише США (62 млн. т. відповідно), на третьому місці Бразилія, яка експортувала 28 млн. тонн. Українська кукурудза також має конкуренту ціну, що сприяє розширенню експортних ринків. 
Таблиця 2

Провідні експортери кукурудзи у 2018 році

\begin{tabular}{|l|c|c|c|}
\hline \multicolumn{1}{|c|}{ Регіон } & Виробництво (млн. т.) & Вартість експорту (млрд. дол. США) & \% від загального світового експорту \\
\hline США & 62,0 & 12,9 & 38,1 \\
\hline Аргентина & 26,5 & 4,2 & 12,5 \\
\hline Бразилія & 28,0 & 4,1 & 12,1 \\
\hline Україна & 28,5 & 3,5 & 10,3 \\
\hline Франція & 4,3 & 1,7 & 5,0 \\
\hline Румунія & 3,9 & 1,0 & 3,0 \\
\hline Угорщина & 3,5 & 0,8 & 2,3 \\
\hline Південна Африка & 1,6 & 0,5 & 1,3 \\
\hline Канада & 1,6 & 0,4 & 1,2 \\
\hline
\end{tabular}

Джерело: Розраховано за даними (Leading corn-exporting countries worldwide 2018/19, 2019)

Одним з чинників поліпшення економічної привабливості ринку зерна в Україні $є$ розвиток експортного потенціалу. Щорічні дані Європейської комісії, оприлюднені наприкінці червня, підтвердили, що Україна зараз $є$ третім за величиною експортером сільськогосподарської продукції до ЄС та одним 3 найбільших у світі експортерів зерна. США наразі $€$ номер один експортером сільськогосподарської продукції в Європейський Союз із щорічним обсягом 12,9 млрд. євро. Друге місце після Америки займає Бразилія (11,7 млрд. євро), а Україна (6,3 млрд. євро) є на третьому місці, випереджаючи Китай (5,9 млрд. євро). За останній рік український експорт продовольства до Європейського Союзу збільшився на 14\%, досягнувши нового максимуму в розмірі 6,3 млрд. євро. Це збільшення дозволило Україні піднятися з п'ятої на третю позицію серед первинних партнерів з продовольчих товарів у $€ C$, підкресливши переваги вільної торгівлі завдяки Угоді про асоціацію між ЄС та Україною, а також допомогло країні відвоювати свою репутацію житниці Європи.

Однак Європа не є єдиним місцем, де українська сільськогосподарська продукція завойовує частку ринку. За останні п'ять років географічне охоплення сільськогосподарського експорту України значно розширилося, оскільки агропідприємства країни вийшли за рамки традиційних ринків колишнього Радянського Союзу з прагненням розширити свою присутність в Азії, Африці та інших країнах.

Основними ринками збуту залишаються три регіони країни Азії, Європейського Союзу та Африки. Загалом на них припадає понад 90\% вартості українського експорту сільгосппродукції. Азійські країни за січень-вересень 2019 року закупили української сільгосппродукції на 6529 млн. дол. США (експорт зріс на 0,8 млрд. дол. США). Частка Азії за цей період склала 41,4\% від загального експорту аграрної продукції, а третина вітчизняного експорту сільгосппродукції 33,9\% - припадає на країни Європейського Союзу. За дев'ять місяців 2019 року вони закупили українського продовольства на 5344 млн. дол. США (поставки збільшилися на 1,2 млрд. дол. США). Обсяги експорту до країн Афррики склали 2400 млн. дол. США (більше на 0,7 млрд. дол. США) - 15,2\% від загального експорту аграрної продукції. Китайська Народна Республіка є найбільшим ринком для України, її частка становила 8,9\% від загального експорту сільського господарства на суму 795 млн. дол. США На другому місці Індія (8,3\%, 741 млн. дол. США), на третьому Єгипет (8,2\%, 737 млн. дол. США), на четвертому Туреччина $(7,6 \%, 684$ млн. дол. США) та на п'ятому Нідерланди (7,1\%, 641 млн. дол. США). Інші основні ринки включали Іспанію (503 млн. дол. США), Італію (333 млн. дол. США), Польщу (301 млн. доларів США) та Німеччину (250 мільйонів дол. США). Дещо менший відсоток припадає на Північну Америку (2,8\%), Латинську Америку $(0,6 \%)$, та Океанію $(0,1 \%)$. Експорт вітчизняної сільгосппродукції до країн СНД скоротився. Країни цього регіону за 9 місяців 2019 року імпортували українського продовольства на 1045 млн. дол. США, що склало 6,6\% від загального експорту аграрної продукції (В Україні зростає експорт агропродовольчої продукції до країн ЄС, Азії та Африки, 2019).

Така диверсифікація ринків збуту є результатом тривалих зусиль 3 модернізації методів ведення сільськогосподарського виробництва України, що призводить до підвищення врожайності, збільшення інфраструктурних можливостей та збільшення врожаю, доступного для експорту.

Обсяги експорту зернових залежать від таких факторів, як експортна ціна зерна, обсяг експорту зерна, співвідношення світової ціни на зерно до внутрішньої ціни, валовий збір зерна в Україні. Аналіз динаміки валового збору й експорту зернових за останні 4 роки в Україні свідчить, що українські виробники постачають на експорт в середньому 66,5\% вирощеного врожаю. (Формування експортного потенціалу України на 2019-2020 МР: чотири агрокроки, 2019)

Найбільше на міжнародних ринках Україна продає зернових культур, серед яких кукурудза, пшениця та ячмінь. Зокрема, у минулому році експорт кукурудзи склав 29,5 млн. т, пшениці - 16,2 млн. т, ячменю - 3,6 млн. т. Крім того, експорт борошна склав 200,1 тис. т. Питома вага товарної групи в загальному обсязі експорту в грошовому вираженні досягла 15,3\%. [Експортний потенціал зернового ринку України оцінюється в 42,6 млн. тонн (Таблиця 3).

Таблиця 3

Валовий збір та експорт зерна в Україні

\begin{tabular}{|l|r|r|r|r|r|}
\hline \multicolumn{1}{|c|}{ Маркетинговий рік } & Площа, млн. га & \multicolumn{1}{|c|}{ Урожайність, т/га } & Валовий збір, млн. т & \multicolumn{1}{c|}{ Експорт, млн. т } & \% експорту \\
\hline $2016-2017$ & 14,3 & 4,6 & 66,1 & 43,8 & 66,3 \\
\hline $2017-2018$ & 14,6 & 4,2 & 61,3 & 39,4 & 64,3 \\
\hline $2018-2019$ & 14,8 & 4,7 & 70,1 & 50,4 & 71,9 \\
\hline $2018 / 2019$ до 2016/2017 (+/-) & 0,5 & 0,1 & 4,0 & 5,6 & 5,6 \\
\hline $2018 / 2019$ до 2016/2017 (\%) & 103,5 & 102,2 & 106,1 & 115,1 & - \\
\hline
\end{tabular}

Джерело: Розраховано за даними (3 початку 2019/20 МР Україна експортувала 18 млн. тонн зерна та борошна, 2019) 
За даними Міністерства аграрної політики і продовольства, за період з 2016 по 2018 рр. валовий збір зерна збільшився на 4 млн. т або на 6,1\%. Дане зростання відбулося за рахунок впливу екстенсивних та інтенсивних факторів. Так, посівні площі, зайняті під зерновими, зросли на 0,5 га, що становить 103,5\%, а урожайність за вказаний період зросла на 2,2\%. Доля експорту зернових за вказаний період збільшилася на 5,6\%. У 2018-2019 МР Україна експортувала рекордні 50,4 млн. тонн зерна (71,9 \% від валового збору), що на 26,1\% більше в порівнянні з попереднім маркетинговим роком. За цим показником наша країна входить у трійку найбільших сві- тових експортерів зерна разом із США (93,1 млн. т) та Європейським Союзом (37,8 млн. т).

Експорт зернових культур з України з початку 20192020 МР склав загалом 17,94 млн. тонн, що на 5 млн. тонн (або на 51,5 \%) вище, ніж за аналогічний період попереднього сезону. Про це свідчать дані Державної фіскальної служби. В розрізі культур експортовано пшениці - 10,7 млн. т; ячменю 3,2 млн. т; жита - 5 тис. т; кукурудзи - 3,4 млн т. При цьому, обсяги експорту пшениці з початку сезону зросли майже на $40 \%$, постачання ячменю зросло на 40,7\%. Експорт кукурудзи на зовнішні ринки за звітний період вище в 1,7 рази за минулорічний (Рудь І., 2019)

Таблиця 4

Експорт зерна в Україні по роках (млн.. тонн)

\begin{tabular}{|l|l|l|l|l|l|l|}
\hline Категорія продукта & \multicolumn{1}{|c|}{$\begin{array}{c}2014 / 2015 \\
\text { MP }\end{array}$} & $2015 / 2016$ MP & 2016/2017 MP & 2017/2018 MP & 2018/2019 МР & 2018/2019 до 2014/2015 МP \\
\hline Пшениця & 17,4 & 18,1 & 17,8 & 16,0 & 19,5 & 11,9 \\
\hline Кукурудза & 16,6 & 21,3 & 18,0 & 29,5 & 30,0 & 80,7 \\
\hline Ячмінь & 4,4 & 5,3 & 4,3 & 3,6 & 4,8 & 9,1 \\
\hline
\end{tabular}

Джерело: Розраховано за даними (Ukraine Barley Exports by Year, 2019)

Аналізуючи експорт зерна в розрізі окремих культур, можна сказати, що по вибраним культурам, таким як пшениця, кукурудза та ячмінь, починаючи з 2014/2015 маркетингового року спостерігається зростання на $11,9 \%, 80,7 \%$ та 9,1\% відповідно

За останнє десятиліття світовий попит на зерно, як основу продовольчого і фуражного раціону, збільшився на $50 \%$. Україна - одна з небагатьох країн світу, враховуючи наявні ресурси, може збільшити виробництво с/г культур, наростити експортні потужності та забезпечити світові потреби. За останні п'ять років тенденція валового збору й експорту зернових з України стабільна. Так, на внутрішні потреби в країні залишається 21-23 млн. тонн зерна, а експорт у середньому становить 66,5 \% від отриманого врожаю.

Поточна траєкторія зростання експортного потенціалу України продовжуватиметься і в найближчі роки, і за прогнозами країна збільшить експорт зерна щонайменше на $40 \%$, досягнувши річних обсягів у 70 мільйонів тонн. Щомісячні обсяги експорту в 6 мільйонів тонн протягом поточного сезону продемонстрували, що сільськогосподарська інфраструктура України , здатна впоратися з таким зростанням. На розвиток експортного потенціалу може суттєво вплинути припинення мораторію на продаж сільськогосподарських земель в Україні та створення довгоочікуваного ринку землі (Ukraine is emerging as the world's next agricultural superpower, 2019)

На експортні можливості України прямо впливає інституційна складова. Актуальною на сьогодні $є$ ухвалена 10 липня 2019 р. Стратегія розвитку експорту продукції сільського господарства, харчової та переробної промисловості України до 2026 року, розроблена Міністерством аграрної політики та продовольства України спільно з Офісом підтримки реформ Міністерства. Метою Стратегії $€$ визначення довгострокової державної політики, спрямованої на забезпечення стабільного нарощування обсягів експорту продукції (товарів, послуг, технологій) вітчизняного сільського господарства, харчової та переробної промисловості (В Україні ухвалили аграрну стратегію до 2026 року, 2019).

Так, стратегічними напрямками розвитку експорту аграрної продукції стане зростання обсягу виробництва та збільшення постачань такої продукції на зовнішні ринки; розширення номенклатури та зміна структури експорту в напрямку збільшення частки продукції з високою доданою вартістю; географрічна диверсифрікація напрямків експорту (відкриття нових ринків) і розширення експортних можливостей для малих та середніх підприємств.

Реалізація Стратегії дасть змогу забезпечити:

- формування дієвої системи інструментів оцінки експортного потенціалу та потенційної привабливості ринків за основними видами продукції сільського господарства, харчової та переробної промисловості;

- належний рівень підтримки вітчизняних експортерів сільськогосподарської продукції та продукції харчової та переробної промисловості як усередині країни, так і за її межами;

- гармонізацію вітчизняного законодавства у частині санітарних та фітосанітарних заходів з європейськими нормами, стандартами та правилами;

- зміну співвідношення між сировиною, продуктами первинної переробки та готовою продукцією в загальному обсязі експортованої продукції сільського господарства, харчової та переробної продукції;

- збільшення експорту продукції сільського господарства, харчової та переробної промисловості протягом строку реалізації Стратегії на 17 відсотків (Про схвалення Стратегії розвитку експорту продукції сільського господарства, харчової та переробної промисловості України на період до 2026 року, 2019).

Висновки. Підсумовуючи вищенаведене, можна сказати, що при збереженні високих темпів нарощування обсягів виробництва сільськогосподарської продукції, агропромисловий сектор має значний додатковий нереалізований потенціал щодо нарощування експорту продукції з доданою вартістю. Подальший його розвиток (за умови стійкого забезпечення продовольчої безпеки держави) здатен не лише закріпити за Україною статус надійного постачальника якісного доступного продовольства на світовий ринок, але і стати потужним рушієм розвитку економіки та зростання добробуту населення, сприяти сталому розвитку сільського господарства, реалізовуючи при цьому потужний виробничий та експортний потенціал. 


\section{Список літератури:}

1.Andriychuk VG Zubets MV, Yurchishin VV (2015) Contemporary Agrarian Policy: Problematic Aspects. K.: Agrarian Science. $381 \mathrm{p}$.

2.Boyko VI (2004) Toward a problem of grain market formation. APK economy. No. 3. P. 35-38.

3.Bodnar OV (2010) Formation of price tendencies in the grain market of Ukraine. Science. hanging Nat. untu biores. and nature. Of Ukraine. Issue 154.1. Available at: http://www.nbuv.gov.ua. (Accessed 10/01/2019).

4.Dels SV (2016) Transportation Approaches to Evaluating the Effectiveness of Export Grain Delivery Schemes. Logistics. No. 11. C. 44

5.Kirilov Yu.E. (2005) Ukraine's Prospects in the Global Grain Market. APK economy. №8. Pp. 135-139.

6.Kutsenko IV (2016) Development of grain procurement and marketing infrastructure of integrated agrarian units. Scientific Bulletin of the International Humanities University. No. 2. P. 155-158.

7.Melnyk TM (2008) Export potential of Ukraine: evaluation methodology and analysis. Available at: http://iepjournal.com/journals/8-9/2008_10_Melnuk1.pdf. (Accessed 10/01/2019).

8. Rodionova MR (2014) Improving the grain market infrastructure. Visn. NAIL. K .: NAIL. No. 8, pp. 15-19.

9. Sabluk RP, Kovalenko OV (2009) Current Trends in Global Grain Trade. APK economy.No. 9. S. 84-88.

10. In 2018, Ukraine has set a record for agricultural exports. (2019). Available at: https://www.unian.ua/economics/agro/10416159-ukraina-v-2018-roci-vstanovila-rekord-z-eksportu-silgospprodukcije.html. (Accessed 10/01/2019).

11. Ukraine is increasing its exports of agricultural food products. (2019) Available at: http://ucab.ua/ua/pres_sluzhba/novosti/ukraina_naroschue_eksport_agroprodovolchoi_produktsii. (Accessed 10/01/2019).

12. Leading corn-exporting countries worldwide 2018/19. (2019) Available at: https://www.statista.com/statistics/254299/topglobal-corn-exporters. (Accessed 10/01/2019).

13. Agri-food exports to the EU, Asia and Africa are increasing in Ukraine (2019) http://agro-yug.com.ua/archives/30068. (Accessed 10/01/2019).

14. Formation of Ukraine's export potential for 2019-2020 MR: four agrocrocks. (2019) Available at: https://landlord.ua/news/formuvannia-eksportnoho-potentsialu-ukrainy-na-2019-2020-mr-chotyry-ahrokrokyyu. (Accessed 10/01/2019).

15. Since the beginning of 2019/20, Ukraine has exported 18 million tonnes of grain and flour. (2019) Available at: https://minagro.gov.ua/en/news/z-pochatku-201920-mr-ukrayina-exportuvala-18-mln-tonn-zerna-ta-boroshna.

(Accessed 10/01/2019).

16. Rud I. (2019) Harvest-2019: main features and preliminary results. Available at: http://nbuviap.gov.ua/index.php?option=com_content\&view=article\&id=4462:urozhaj-2019-personality-tsogorichnikh-zhniv\&catid=8\&ltemid=350. 10/01/2019).

17. Ukraine Barley Exports by Year (2019). Available at: https://www.indexmundi.com/agriculture/?country=en\&commodity=barley\&graph=exports. (Accessed 10/01/2019).

18. Ukraine is emerging as the world's next agricultural superpower (2019). Available at: http://bunews.com.ua/economy/item/ukraine-feeds-the-world. (Accessed 10/01/2019).

19. Ukraine has adopted an agricultural strategy until 2026. (2019) Available at: https://edumka.com/2019/07/13/v-ukrayiniuhvalyly-agrarnu-strategiyu-do-2026-roku. (Accessed 10/01/2019).

20. On approval of the Strategy for development of export of agricultural products, food and processing industry of Ukraine for the period until 2026. Ordinance of the Cabinet of Ministers of Ukraine dated July 10, 2019 No. 588-p. Available at: https://zakon.rada.gov.ua/laws/show/588-2019-\%D1\%80 . (Accessed 01/10/2019).

Maryna Solovey, postgraduate studet, Sumy National Agrarian University (Sumy, Ukraine)

\section{Grain export: state, problems and prospects}

Currently, Ukraine is one of the world leaders in agricultural export. Due to its favorable climate and geographical location, unique natural resources and large areas of fertile arable land, Ukraine is well positioned to become a world leader in agricultural production.

The purpose of this article is to analyze the situation on the grain market, determine trends, the capacity of the grain market and export potential of Ukraine.

The methods used in the present studies include the method of analysis for the assessment of the grain market, the method of comparison for the analysis of the export potential of the world grain market, the method of logical generalization in summarizing the results of this study.

The article reviews the export potential of the grain market in Ukraine and the world. Analyzing the data, we came to the following conclusions. Ukraine accounts for 7.5 percent of total global wheat exports, which puts it in the sixth place in the world. Positive growth trends in the export percentage by 15.5\% in comparison with 2018 indicate that Ukraine is gradually entering the top three world grain exporters.

Consideration of export potential in the context of selected crops shows that since 2015, there has been a tendency to increase the growth rates for wheat by 11.9 percent, for corn by 80.7 percent, for barley by 9.1 percent.

The article concludes that, while maintaining a high rate of increase in agricultural output, the agro-industrial sector has significant additional untapped potential to increase the exports of value-added products. Its further development (provided the sustainable food security of the state) is capable not only to consolidate Ukraine's status as a reliable supplier of high-quality affordable food 
products to the world market, but also to become a powerful engine for economic development and increase of the population welfare, contribute to the sustainable development of agriculture, while realizing a powerful production and export potential.

Keywords: grain market, export potential, foreign trade, European integration

Дата надходження до редакції: 05.02.2019 р. 